VOL 4 (2020) NO 4

e-ISSN : 2549-9904

ISSN : 2549-9610

INTERNATIONAL JOURNAL ON INFORMATICS VISUALIZATION

\title{
Developing Blueprint for Public Services Information System in the District of Indonesia using Enterprise Architecture Planning Method
}

\author{
Yuli Maulani ${ }^{\# 1}$, Sri Lestari ${ }^{\# 2}$ \\ \# Department of Information System, Widyatama University, Bandung, Indonesia \\ E-mail: ${ }^{1}$ yuli.maulani@widyatama.ac.id, ${ }^{2}$ sri.lestari@widyatama.ac.id
}

\begin{abstract}
Local government agencies, namely districts as regional technical implementers, are inseparable from the obligation to implement information technology, or better known as e-government, to create cohesiveness. Information systems in the district support the implementation of daily activities by only taking into account current needs without regard to conformity with the vision and mission and future needs of the district. Districts need careful planning in the form of architecture to complete the direction of the subdistrict strategy. This study aims to create a blueprint for developing information systems using the Enterprise Architecture Planning (EAP) methodology. Blueprint is designed to produce four main activities in the district, namely planning, government administration, integrated services, and governance with ten recommendations for cloud server-based applications, 5 of which use mobile platforms. The app has been mapped in the application portfolio to provide recommendations for implementing the application as a reference, clear guidelines, and plans for the development of the overall information system.
\end{abstract}

Keywords - Blueprint; Public Service; District; Indonesia; Enterprise Architecture Planning.

\section{INTRODUCTION}

Presidential Regulation Number 95 of 2018 in Indonesia concerning Electronic-Based Government Systems (SPBE) takes effect starting in 2018. It is a starting point for all government agencies to apply information technology or better known as e-government, to create cohesion. With this policy, it has an impact on local government institutions, namely the districts as regional technical implementers. With this policy, it has an impact on local government institutions, namely the districts as regional technical implementers [1]. They implement information technology to support their daily activities by only paying attention to the needs of the moment without regard to conformity with the organization's vision and mission. This can be seen from several complaints from the public on the LAPOR portal, where the processing of population data services is still manual, so the community must prepare various population related files when they want to apply. There is no clear information regarding the time and status of the application submitted by the district [2].

Based on the above problems, the information system has not provided broad access and achieved alignment of the mission and objectives of the organization in meeting needs. So the need for an integrated district information system in data management and decision making.
Information systems in districts must develop careful planning because the lack of planning in developing information systems will be almost complete in the direction of district strategies. Careful planning in the form of architecture. The architecture here as befits a blueprint, depiction, or model [3].

This study aims to make a blueprint for developing information systems as a reference, guidelines, and clear plans for the development of information systems as a whole. Blueprint created using the Enterprise Architecture Planning (EAP) methodology.

Research using Enterprise Architecture Planning in the Zachman framework has been carried out in various corporate environments ranging from the educational environment [4],[5],[6] to the government environment [7] If you look at the scope of research that is more specific at the local government level that includes districts [8],[9] several plans to develop information systems and information technology that are tailored to the needs with different focus while this research focuses on the blueprint for public service-oriented needs such as application tracking applications to provide information related to requests that have been submitted whether they are still in process or have been processed and display a definite date associated with the collection of correspondence 


\section{The MATERIAL AND METHOD}

The research steps refer to the Enterprise Architecture Planning (EAP) methodology. Enterprise Architecture Planning is a process of defining the architecture for information users in supporting businesses and plans to implement the architecture [10]. Zachman's framework maps EAP in the first two rows, which are the perspectives of planners and owners as well as the first three columns covering data, functions, and network information system architecture.

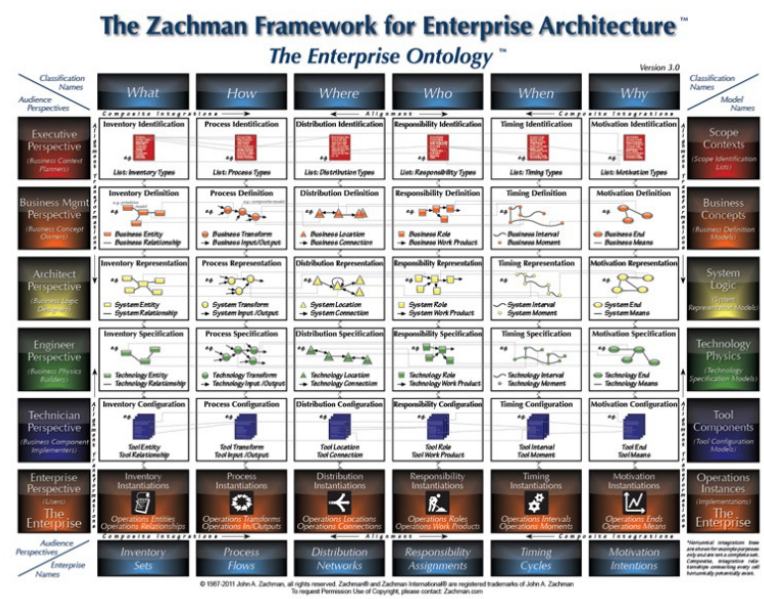

Fig. 1 The EAP Approach in the Zachman Framework [11]

Corporate Architecture Planning has seven main components that indicate the stages of determining and planning the implementation of information systems architecture. These seven main components are classified into four layers [12], which can be seen in figure 2 .

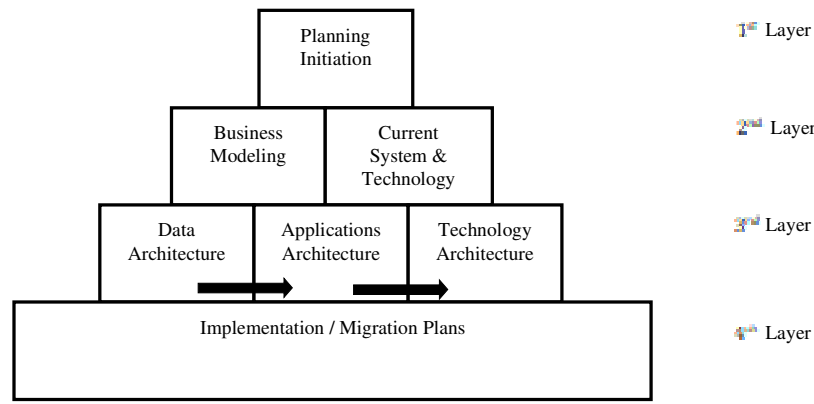

Fig. 2 Components in Enterprise Architecture Planning [12]

These steps can be seen in the following research framework:

\section{A. Literature Study}

At this stage, a search for materials or literature is needed to support and dig deeper related to the theory and initial discussion of the topics taken.

\section{B. Data Collection}

Data collection was carried out with two events, as follows:

1) Observation: Observation is a direct observation of the research location to see activities or things or documents that occur at the place, which are useful as data in research preparation. Observations were made in Bandung City Regency.

2) Interview: Conduct interviews with officials or employees in the districts related to IT or parties related to research.

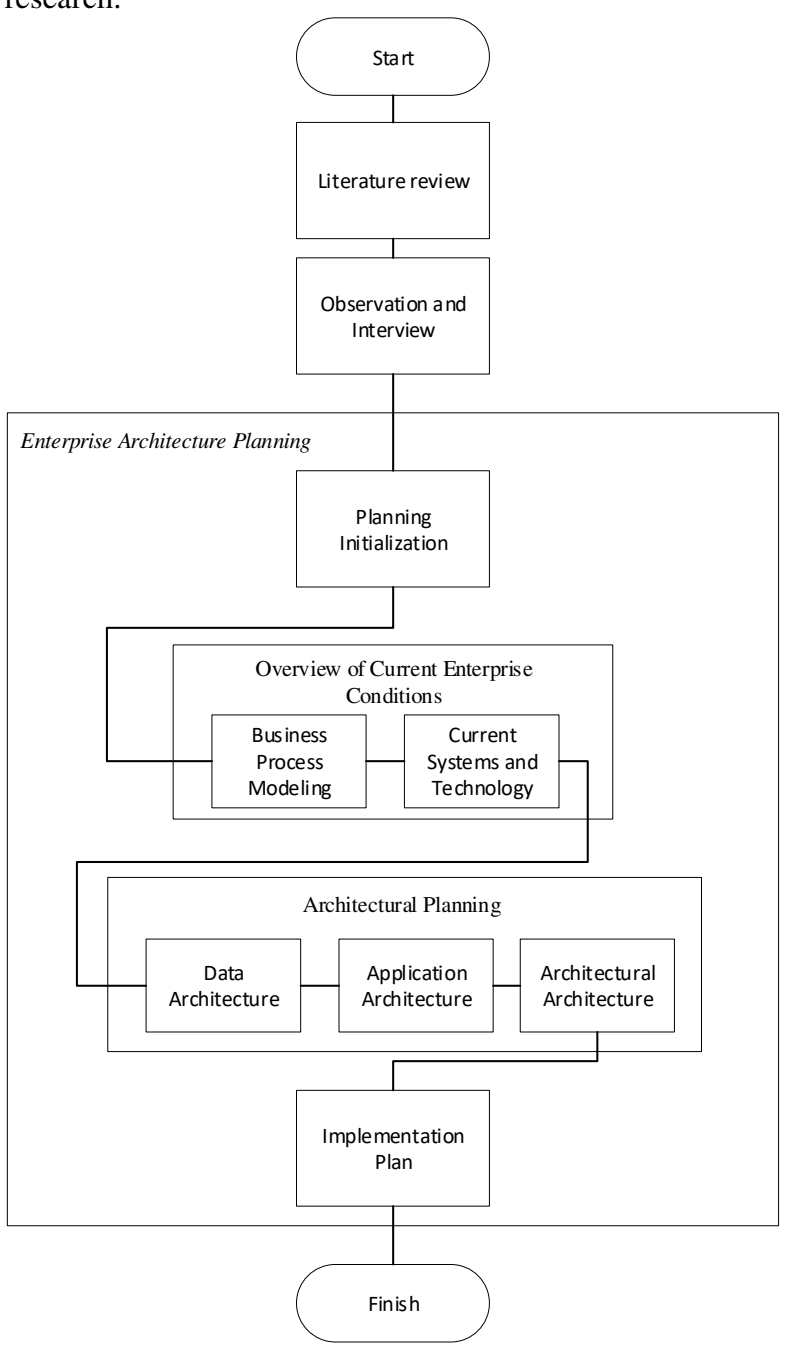

Fig. 3 Research Framework

C. Planning Initiation

The definition is related to the rules that become a reference to determine the scope, objectives, determination of the methodology, tools used, team planning, and activity plans to produce more targeted planning.

\section{Overview of Current Enterprise Conditions}

At this layer consists of two stages, namely business modelling includes defining business function models using value chains for modelling and systems or technology currently provides documentation of all systems and technology platforms that are being used by the enterprise. The results of the literature are called the Information Resource Catalog (IRC) or also called the System Inventory, which contains a brief description of the system.

\section{E. Architectural Planning}

At this layer, there are three stages: data architecture, application architecture, and technology architecture. 
1) Data Architecture: There are several steps in defining data architecture, including making a list of candidate data entities so that all potential data entities that are useful for business support can be defined by taking into account the data requirements of each predefined business function. Data entities are part of business entities that consist of tables that contain fields and information system data records [13]. Relationship diagrams between data entities are explained using Entity-Relationship Diagrams (ERD) as well as creating a matrix mapping of data entity relationships and business functions to connect data entities with business functions

2) Application Architecture: Description of the application needs to be built to make the application architecture, so it needs to identify the application, determine the purpose of the application, specifications, capabilities, benefits, operational needs, architectural schemes, and identify each application unit in the aspect of function. Create activity type functions for data (in the CRUD matrix) and application relationships to organizational units and associations with the applicable system.

3) Technology Architecture: Technology architecture is the definition of technology or platform that supports business functions so that identification and definition of technological principles or platforms required by the district are needed to manage data so that business functions can run well.

\section{F. Implementation Plan}

The implementation plan is the defining stage related to the recommendations for the implementation plan based on the architecture that has been made previously. The steps in creating an implementation plan are determining the priorities of application development, estimating the implementation of the implementation, and making the final report of architectural planning

\section{RESULTS AND DISCUSSION}

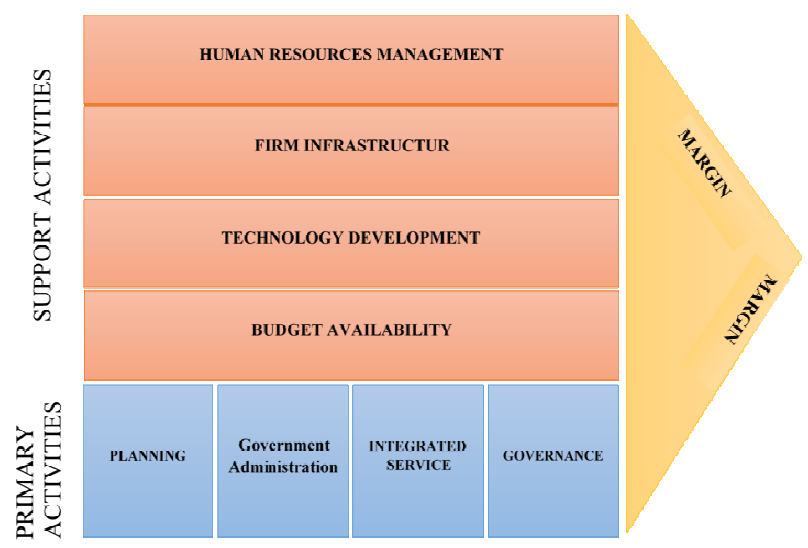

Fig. 4 Value Chain Analysis

\section{A. Planning Initiation}

The objective of this research is to model public service systems that are integrated and supported by information technology in the implementation of core district business processes and needs and can support the achievement of the vision of districts in Indonesia.

\section{B. Overview of Current Enterprise Conditions}

There are two stages in this layer as follows:

1) Business Modeling: Business modelling is done by changing business functions. The tool used to classify business functions is business value chain analysis in the group field [14].

Based on the results of the value chain analysis, the main activities of the districts consist of the planning process, governance, population services, and governance. The following is a hierarchical chart of the central district activities:

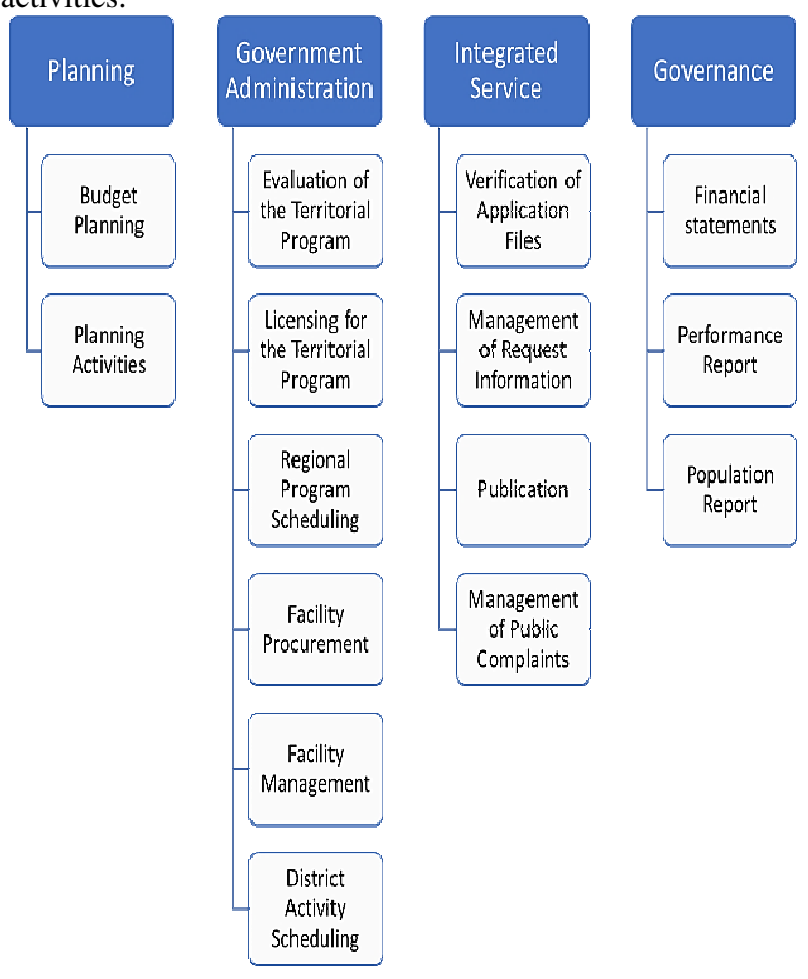

Fig. 5 Hierarchy Chart

\section{2) Current System and Technology}

Based on the results of the analysis of observations and interviews conducted, the existing systems and technologies in the districts are:

1. Assessment Information System is a system that is useful for managing activity reports to become a Diskominfo evaluation.

2. Financial Information System is a system for allocating and managing budgets.

3. Goods Data Information System, or abbreviated as SIMDA, is an application used to manage district inventory.

4. Service Application is an application managed by Disdukcapil in handling services to the public, such as correspondence related to population documents. Subdistrict only as of the user (admin), not a manager.

5. Personnel Information System, or abbreviated as SIMPEC, is an application that is used for employee attendance when they come and when employees go home in the district to use Face Recognition technology to determine employee performance in terms of presence.

6. Technology Infrastructure 
TABLE I

TECHNOLOGY INFRASTRUCTURE

\begin{tabular}{|l|l|l|}
\hline No & Technology & Details \\
\hline 1 & hardware & $\begin{array}{l}\text { pc }(10 \mathrm{pcs}) \\
\text { laptop }(3 \mathrm{pcs}) \\
\text { handphone }(13 \mathrm{pcs})\end{array}$ \\
\hline 2 & software & windows 7-10, PHP, MySQL \\
\hline 3 & communication & LAN, internet, wifi \\
\hline
\end{tabular}

\section{Architecture Planning}

This stage is the stage to create three architectures that contain data architecture, application architecture, and technology architecture following the previous identification steps.

1) Data Architecture: The purpose of making architectural data is to create data that will be used in architectural application development. The results of the data class identification will then be validated to find out what data is entered and used by each process and what data is generated.

Linking business processes with data entities using a matrix of data class relationships with processes where several symbols represent the relationship between the two include [12]: $\mathrm{C}$ (create) that is the process that creates data classes, $U$ (Update/Changed) that is the process that changes the data class, dan $\mathrm{R}$ (Referenced/Used) that is, the process that uses data classes.

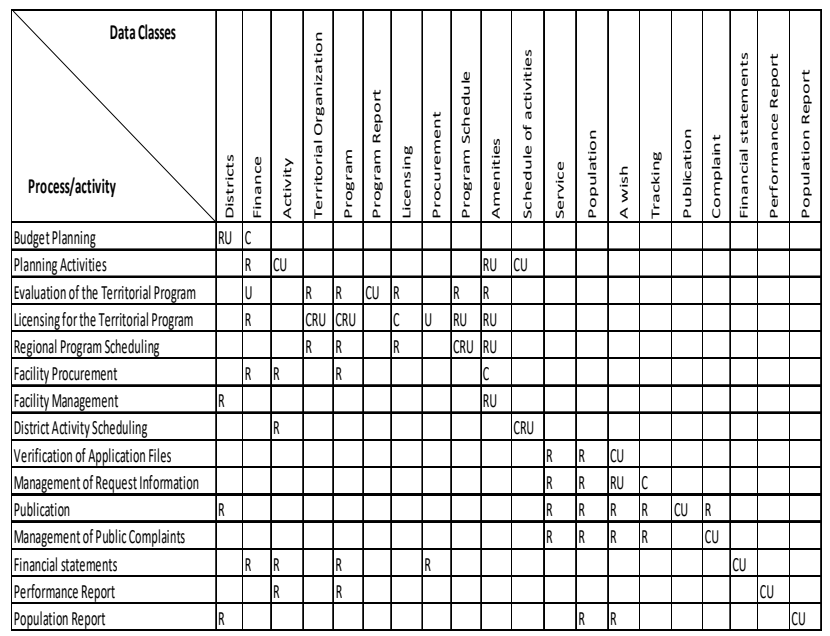

Fig. 6 Matrix Relationship between Data Classes and Processes

2) Application Architecture:The steps in defining an application architecture are making a list of candidate applications, correlating applications with business functions, and conducting an impact analysis on existing applications. List of candidate applications in the district :

1. Planning and Budgeting Information Systems

2. Regional Development and Empowerment Information System

This application aims to manage regional territorial organization programs such as youth clubs, Maternal and Child Health Services. So on when they want to submit programs to the district, there is no need to meet face-to-face but instead, provide through a complete system with the required budget and facilities.

3. Procurement Information System

4. Goods Data Information System
5. Activity Scheduling Information System

Activity scheduling Information System contains names, places, times, and organizers of activities both carried out by the district or district and regional organizations to minimize the clash of activities in each region.

6. Application for Submission of Applications

In this application, people no longer need to come to the district to send the application requirements file, for example, making ID cards, people only need to submit requests via their mobile phones wherever and whenever.

\begin{tabular}{|c|c|c|c|c|c|c|c|c|c|c|}
\hline Process/activity & 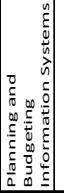 & 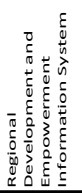 & 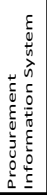 & 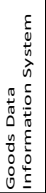 & 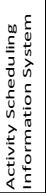 & 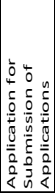 & 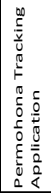 & $\begin{array}{l}\frac{0}{0} \\
\frac{5}{0} \\
\frac{0}{0} \\
3 \\
\frac{0}{0} \\
\frac{5}{0} \\
\frac{0}{0}\end{array}$ & $\begin{array}{l}\bar{\sigma} \\
0 \\
0 \\
0 \\
0 \\
0 \\
0 \\
0 \\
\alpha \\
\alpha\end{array}$ & 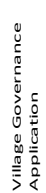 \\
\hline Budget Planning & U & & & & & & & & & \\
\hline Planning Activities & U & & & & & & & & & \\
\hline Evaluation of the Territorial Program & & U & & & & & & & & \\
\hline Licensing for the Territorial Program & & $U$ & & & & & & & & \\
\hline Regional Program Scheduling & & U & & & & & & & & \\
\hline Facility Procurement & & & U & & & & & & & \\
\hline Facility Management & & & & U & & & & & & \\
\hline District Activity Scheduling & & & & & U & & & & & \\
\hline Verification of Application Files & & & & & & U & & & & \\
\hline Management of Request Information & & & & & & & $U$ & & & \\
\hline Publication & & & & & & & & U & & \\
\hline Management of Public Complaints & & & & & & & & & U & \\
\hline Financial statements & & & & & & & & & & $U$ \\
\hline Performance Report & & & & & & & & & & $U$ \\
\hline Population Report & & & & & & & & & & $U$ \\
\hline
\end{tabular}

Fig. 7 Application and Process Relationship Matrix

7. Application Tracking Application

This application provides information to the applicant related to requests submitted on the application for submission of applications where the public can see the status of their letters, the state of a collection of letters, and estimates of when the letter was completed

8. District Website

This website contains district profile information and notifications related to population data as well as a place for publication of activities carried out.

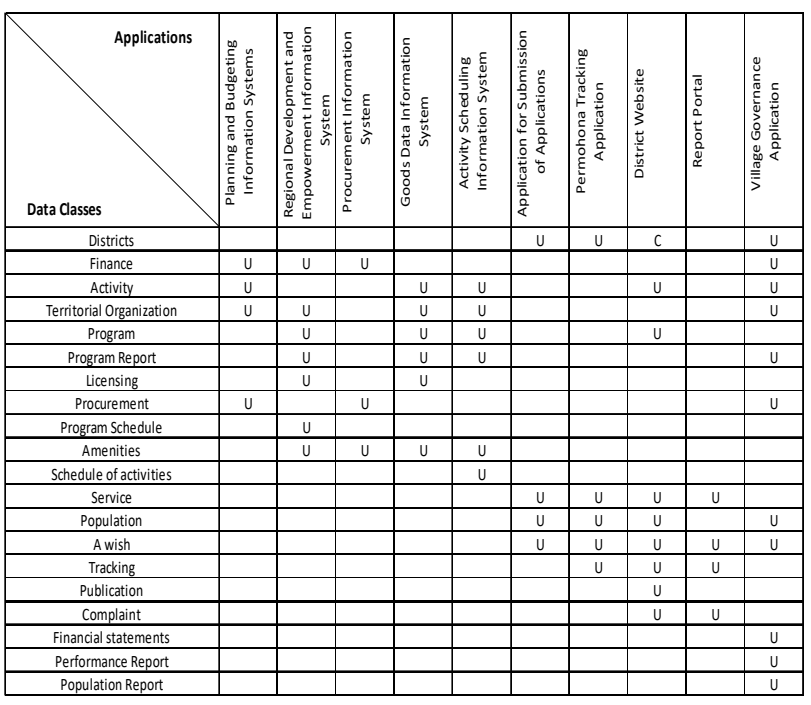

Fig. 8 Application Relationship Matrix and Data Classes 
9. Report Portal

A portal that facilitates the community to complain or provide input to services in the district.

10. Village Governance Applications

This application is useful for making financial reports, performance achievements and population statistics that are of concern to local governments to evaluate district performance.

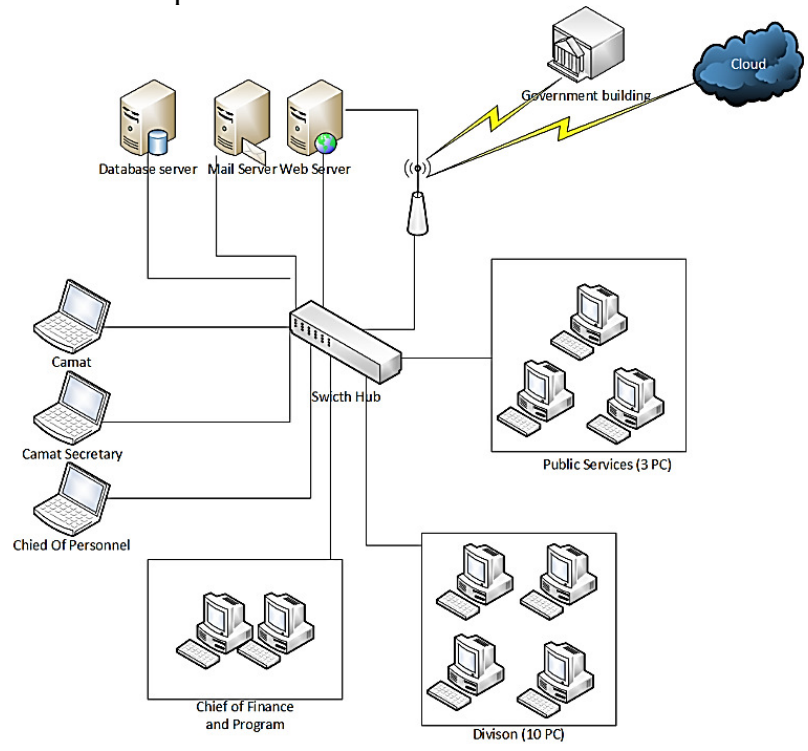

Fig. 9 Technology Architecture

\begin{tabular}{|c|c|c|c|c|c|c|c|c|c|c|c|}
\hline \multirow[b]{3}{*}{ Application } & \multicolumn{5}{|c|}{ Software } & \multirow{2}{*}{\multicolumn{3}{|c|}{$\begin{array}{c}\text { Networking } \\
\text { Network and Device }\end{array}$}} & \multirow{2}{*}{\multicolumn{2}{|c|}{ Platform }} & \multirow{3}{*}{ SMS Gateway } \\
\hline & \multicolumn{2}{|c|}{ Operation System } & \multicolumn{2}{|c|}{\begin{tabular}{|l} 
Programming \\
\end{tabular}} & \multirow{2}{*}{\begin{tabular}{|c|} 
DBMS \\
MSSQL
\end{tabular}} & & & & & & \\
\hline & Windows & Mobile & PHP & Java & & LAN & Internet & Switch HUB & Web & Mobile & \\
\hline 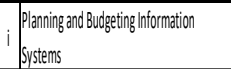 & $v$ & & $v$ & & $v$ & $\checkmark$ & & $\checkmark$ & $v$ & & \\
\hline ii $\begin{array}{l}\text { Regional Development and Empowerment } \\
\text { Information System }\end{array}$ & $v$ & $v$ & $\checkmark$ & v & v & & $\checkmark$ & V & $v$ & $\checkmark$ & $\checkmark$ \\
\hline \begin{tabular}{l|l} 
iii & Procurement Information System \\
\end{tabular} & 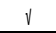 & & 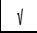 & & 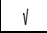 & $v$ & & 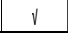 & V & & \\
\hline iv Goods Data Information System & 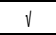 & & 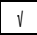 & & 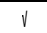 & 1 & & 1 & $\sqrt{ }$ & & \\
\hline \begin{tabular}{l|l}
$v$ & Activity Scheduling Information System \\
\end{tabular} & V & V & 1 & 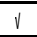 & 1 & & $V$ & 1 & 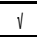 & 1 & \\
\hline \begin{tabular}{l|l} 
vi & Application for Submission of Applications \\
\end{tabular} & 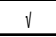 & $v$ & 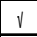 & $V$ & 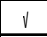 & & 1 & 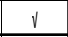 & $\checkmark$ & 1 & $\checkmark$ \\
\hline vii Submission Trading Application & $v$ & V & V & $V$ & $v$ & & $v$ & 1 & 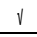 & 1 & 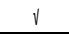 \\
\hline viii |District Website & 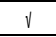 & & 1 & & V & & 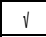 & 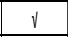 & 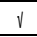 & & \\
\hline \begin{tabular}{|l|l|} 
ix & ReportPortal \\
\end{tabular} & $\sqrt{ }$ & $\checkmark$ & 1 & V & V & & $v$ & $v$ & 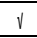 & 1 & $v$ \\
\hline 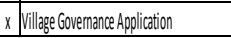 & 1 & & 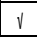 & & V & & 1 & 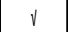 & V & & \\
\hline
\end{tabular}

Fig. 10 Application and Technology Relations

The cloud server is a flexible data storage option that has no impact when one of the servers is corrupted, making data storage safer. Platform selection is essential when the convenience offered by the mobile platform supports service-oriented applications, such as those intended for ii, vi, vii, ix applications. The web platform reaches people in Indonesia who do not have cellphones. SMS Gateway becomes a complementary technology in providing notifications to users.

\section{Implementation Plan}

After making an architectural plan, the next step is to create an implementation plan that requires hundreds of implementations of the application plan to be built and implemented in the district.
McFarlan's portfolio is useful for mapping applications/information systems based on their contribution to the company. McFarlan's portfolio is divided into 4 (four) quadrants, viz [15]:

1. High potential applications

This application has a high potential for the district in the future. Apps in this quadrant are still in the exploratory stage and cannot be used yet.

2. Strategic application.

Applications in this quadrant have an essential role for the district as a tool to achieve the main objectives and increase the community satisfaction index.

3. Key operational applications

Applications in this quadrant play an essential role for districts to continue to operate and run.

4. Application support

The application in this quadrant is essential but does not directly support the district's success.

Based on the results of the application architecture planning and its relationship with the district business processes, the application sequence has been mapped based on the implementation plan in Table II.

\begin{tabular}{|c|c|}
\hline STRATEGIC & HIGH POTENTIAL \\
\hline $\begin{array}{ll}- & \text { District Website } \\
\text { - } & \text { Report Portal } \\
& \text { (Mobile) } \\
-\quad & \text { Application for } \\
& \text { Submission of } \\
\text { Applications } \\
\text { (Mobile) }\end{array}$ & $\begin{array}{ll}- & \text { Submission Tracking } \\
\text { Application (Mobile) } \\
\text { - } & \text { Planning and Budgeting } \\
\text { Information Systems } \\
\text { - } & \text { Regional Development and } \\
\text { Empowerment Information } \\
\text { System (Mobile) }\end{array}$ \\
\hline $\begin{array}{ll}- & \text { Procurement Information } \\
\text { - } & \text { System } \\
\text { Goods Data Information } \\
\text { System } \\
\text { - Village Governance } \\
\text { Application }\end{array}$ & $\begin{array}{l}\text { Activity Scheduling } \\
\text { Information System } \\
\text { (Mobile) }\end{array}$ \\
\hline KEY OPERATIONAL & SUPPORT \\
\hline
\end{tabular}

Fig. 11 Application Portfolio

\section{CONCLUSIONS}

District level local governments require an information system plan to achieve cohesiveness, the construction of public service information systems using the enterprise architecture method produces ten cloud server-based application proposals, 5 of which use a mobile platform that supports the main business processes in the district. The implementation plan generates references in the development of applications that support district business functions by prioritizing implementation plans based on data-driven advice from Enterprise architecture planning, so applications that produce data can be built first.

\section{REFERENCES}

[1] Government of the Republic of Indonesia, Government Regulation of the Republic of Indonesia Number 19 the Year 2008 Concerning Districts. 2008..

[2] Pemerintah Republik Indonesia, "Layanan Aspirasi dan Pengaduan Online Rakyat (LAPOR!)," Kantor Staf Presiden, 2019. [Online]. 
Available:

https://www.lapor.go.id/instansi/kecamatan-antapanikota-bandung.

[3] A. P. Widodo, "Enterprise Architecture Model Untuk Aplikasi Government," pp. 1-8.

[4] H. Supriyadi, "Enterprise Arsitektur SMK Menggunakan Pendekatan Enterprise Architecture Planning (EAP) dalam Kerangka Kerja Zachman," 2016, pp. 236-241.

[5] S. Reno, "Pengembangan Model Arsitektur Enterprise Sistem Informasi Menggunakan EAP Pada Perguruan Tinggi (Studi Kasus di Universitas Dehasen Bengkulu)," vol. 12, no. 1, pp. 70-78, 2016.

[6] Fatoni, D. Antoni, and E. Supratman, Praktik Architecture Planning. Palembang: Pusatt Penerbiittan dan Percettakan Uniiversiittas Biina Darma Press, 2018.

[7] H. Kurniawan, "Perancangan arsitektur sistem informasi menggunakan enterprise arsitecture planning," J. Inform., vol. 13, no 1 , pp. 41-51, 2013

[8] J. R. Simanjuntak, E. Darwiyanto, M. T. G. A. A. W, and S. Kom, "Perancangan Enterprise Architecture Pemerintahan Kecamatan menggunakan Zachman Framework ( Studi kasus: Kecamatan Dayeuhkolot )," vol. 6, no. 1, 2019.
[9] A. Yudhana et al., "khazanah informatika Perancangan Sistem Informasi Menggunakan Enterprise Architecture Planning ( Studi Kasus Pada Kecamatan di Kota Samarinda )," vol. 4, no. 2, pp. 114 $123,2018$.

[10] S. A. Bernard, An Introduction to Enterprise Architecture: Third Edition. Bloomington, IN 47403: AuthorHouse, 2012.

[11] K. Surendro, "Pemanfaatan Enterprise Architecture Planning untuk Perencanaan Strategis Sistem Informasi," J. Inform., vol. 8, no. 1, 2007.

[12] S. H. Spewak, Enterprise Architecture Planning: Developing a Blueprint for Data, Application, and Technology. 1992.

[13] M. Sobri, P. Indriani, M. T. Ijab, I. Isnawijayani, and M. Marlindawati, "Development of Inventory Information System Using Enterprise Architecture Planning Method," JOIV Int. J. Informatics Vis., vol. 3, no. 4, pp. 321-326, 2019.

[14] 50MINUTES, Michael Porter's Value Chain: Unlock your company's competitive advantage Title. 50 Minutes, 2015.

[15] J. Ward and J. Peppard, Strategic Planning for Information System : Third Edition. New York: John Wiley \& Sons Ltd, 2002.. 